\title{
NEST PREDATION IN AN URBANIZING LANDSCAPE: THE ROLE OF EXOTIC SHRUBS
}

\author{
Kathi L. Borgmann ${ }^{1}$ And Amanda D. Rodewald \\ School of Natural Resources, Kottman Hall, 2021 Coffey Road, Ohio State University, \\ Columbus, Ohio 43210-1044 USA
}

\begin{abstract}
Nest predation is considered a primary force shaping avian communities, and landscape-scale features (e.g., amount of fragmentation) are generally recognized as factors mediating nest predation. These same landscape-scale features, however, may promote invasion by exotic plants, which may, in turn, increase risk of nest predation. We examined whether the use of exotic shrubs (Lonicera spp. and Rosa multiflora Thumb.) affected nest predation across 12 riparian forest sites along a rural-urban gradient $(<1-$ $47 \%$ urban land cover within $1 \mathrm{~km}$ ). From 2001 to 2003, 188 Northern Cardinal (Cardinalis cardinalis) and American Robin (Turdus migratorius) nests $\leq 5 \mathrm{~m}$ tall were monitored. Nest substrate, nest height, and distance from the forest edge were recorded for each nest, whereas nest placement and nest patch characteristics were measured only for Northern Cardinal nests $(n=68)$. To further assess relative rates of nest predation in native vs. exotic shrubs while controlling for nest height, distance to edge, and land use, we conducted an artificial nest experiment at two rural sites. Artificial nests $(n=79)$ were placed at similar heights in honeysuckle, rose, and native nest substrates along a transect $50-75 \mathrm{~m}$ from the forest edge. Nest substrate and landscape type alone failed to account for differences in daily mortality rates. Instead, the effect of nest substrate varied with the landscape matrix, such that nests in exotic shrubs in urbanizing landscapes were twice as likely to be depredated than nests in native substrates, irrespective of distance from the edge. Artificial nests placed in exotic shrubs in rural landscapes also suffered higher rates of nest failure than artificial nests in native substrates. Daily mortality rates were greater for nests in exotic shrubs, likely due to reduced nest height and larger shrub volume surrounding the nest. Nests in exotic shrubs were 1.5-2 m lower to the ground and within patches containing 6-9 times more exotic shrub volume. These differences may improve search efficiency of mammalian predators, which appear to be the main predators at our study sites. Based on marks present on recovered clay eggs, $68 \%$ of the predation events were attributed to mammals. These findings demonstrate that exotic shrubs can reduce nesting success of forest birds and may cause increased nest failure in urbanizing landscapes. This illustrates another way that exotic plants may diminish habitat quality and limit the capacity of urban forests to contribute to wildlife conservation; therefore, restoring the native shrub community may prove beneficial.
\end{abstract}

Key words: American Robin; Cardinalis cardinalis; exotic shrubs; honeysuckle; landscape matrix; multiflora rose; nest characteristics; nest predation; Northern Cardinal; Turdus migratorius; urbanization.

\section{INTRODUCTION}

Nest predation is a common source of nest failure in birds (Ricklefs 1969, Martin 1992, 1993a) and is thought to be a primary selective force shaping nestsite selection (Martin and Roper 1988, Martin 1992, 1993b), nest-site suitability (Martin 1988a), life history traits (Martin 1995), and patterns of avian distribution (Martin 1988b, 1988c, Sieving and Willson 1998, Rodewald and Yahner 2001a). Because nest predation exerts such a strong selective force on birds, research has focused on identifying factors that govern the intensity and frequency of nest predation. Recent work in eastern

Manuscript received 24 March 2003; revised 10 January 2004; accepted 25 February 2004; final version received 22 March 2004. Corresponding Editor: J. D. Brawn.

${ }^{1}$ E-mail: kathiborgmann@ @otmail.com landscapes suggests that landscape-scale factors such as amount of fragmentation and amount of regional forest cover (Robinson et al. 1995, Flather and Sauer 1996, Thompson et al. 2002) and even specific land uses (Rodewald and Yahner 2001a, b, Rodewald 2002) can increase rates of nest predation for forest birds. Many of the same landscape-scale factors (e.g., land uses) that are associated with increased nest predation may also facilitate invasion by exotic plants (Moran 1984, Rottenborn 1997, Hobbs 2000, Borgmann 2002). In riparian forests in Ohio, exotic shrub volume was closely associated with land uses such that, volume of Lonicera spp. (Lonicera maackii (Rupr.) Herder, Lonicera tatarica L.) was positively associated with urbanization in areas that were likely colonized by Lonicera spp. at similar times (Borgmann 2002). Associations between the landscape matrix and invasion have 
important implications because exotic shrubs may reduce nesting success and abundance of birds that are already vulnerable due to urbanization and habitat degradation (Mills et al. 1989, Germaine et al. 1998, Rottenborn 1999, Schmidt and Whelan 1999, Donovan and Flather 2002, Remes 2003). Unfortunately, little empirical data exists to assess how these interactions affect nest success (D'Antonio et al. 2001, Reichard et al. 2001, Byers et al. 2002).

Schmidt and Whelan (1999) provided the first evidence that exotic shrubs negatively affect nest success of forest birds in one Chicago area woodlot. They demonstrated that daily mortality rates were nearly three times higher for nests in exotic shrubs than nests in native shrubs. Because other factors (e.g., distance from edge and landscape matrix) may have produced similar results, we expanded upon their research by using a multi-scale approach to evaluate how the use of exotic shrubs (Lonicera spp. [hereafter honeysuckle] and $R$. multiflora [hereafter rose]) as nest substrates affects nest success. We evaluated how exotic shrubs affect nest success at the landscape scale (land use within $1 \mathrm{~km}$ ), habitat scale (e.g., within a site), and at the nest-site scale (habitat immediately surrounding the nest). The goals of our study were to compare nesting success among exotic and native nest substrates at several sites across a rural-urban gradient and to identify the mechanisms by which exotic shrubs may be responsible for increased nest predation. Specifically, we addressed the following questions: (1) Do daily mortality rates differ among nests $(\leq 5 \mathrm{~m}$ tall) located in honeysuckle, rose, and native nest substrates? (2) Does nest placement (within the nest substrate) and vegetation within the nest patch differ among nests in exotic and native nest substrates? (3) Do differences in vegetation surrounding the nest and nest placement characteristics influence nest fate? (4) Does location of exotic shrubs within the forest contribute to edge related predation?, and (5) Does the landscape matrix mediate these patterns?

\section{Methods \\ Study area}

The study area was located within the Scioto River Watershed in central Ohio. Sites were located within Franklin and Delaware counties on publicly and privately owned lands. Land cover within these two counties was primarily agriculture (44\%) and urban/residential development $(41 \%)$, whereas only $8.5 \%$ of the land cover was forested (USGS EROS Data Center 2000). Remnant forests persist mainly in riparian areas (Laub 1979, Groom and Grubb 2002) and are generally dominated by maple (Acer spp.), black cherry (Prunus serotina Ehrh.), white ash (Fraxinus americana L.), American elm (Ulmus americana L.), cottonwood (Populus deltoids Bartr. ex Marsh.), Ohio buckeye (Aesculus glabra Willd.), and boxelder (Acer negundo L.).
Dominant understory shrubs include honeysuckle, multiflora rose, and, to a lesser extent, native shrubs including spicebush (Lindera benzoin L. Blume) and hawthorn (Crataegus L.).

Potential riparian forest study sites $(\geq 100 \mathrm{~m}$ wide and $>250 \mathrm{~m}$ long) within the watershed were identified from digital orthophoto quadrangle (DOQ) images (USGS DOQ 1994-1995, 1:24 000) and detailed maps of Franklin and Delaware counties. From these, we selected 12 sites that met the following criteria: (1) mature riparian forest, (2) $\sim 100-200 \mathrm{~m}$ wide, (3) $\geq 250$ $\mathrm{m}$ long, (4) $\geq 2 \mathrm{~km}$ between sites, (5) negligible slope $(<5 \%)$, and (6) river width of $\sim 20-40 \mathrm{~m}$. Only eight sites were studied in all years due to time constraints; four additional sites were studied in only one of the three years. We calculated the percentage of land area containing urban, forest, and agricultural cover types within a $1 \mathrm{~km}$ radius for all sites using 1994 Thematic Mapper Imagery data (Ohio Department of Natural Resources, Columbus, Ohio, USA) and ArcView geographic information software (ESRI, Redlands, California, USA) (Table 1). Land covered by pavement or buildings was classified as urban development and open (nonforested areas lacking wetlands or water) vegetation was classified as agriculture. The amount of forest within the landscape was not confounded with urbanization, as the two were not significantly related ( $r=$ $-0.53, P=0.08)$. Because percent cover by agriculture and urban land cover were negatively correlated $(r=$ $-0.63, P=0.03$ ), only percent urban land cover was used in analyses, as this was the focus of our work.

\section{Nest monitoring}

We searched for and monitored nests of Northern Cardinals and American Robins. Each site was searched for active nests from May to early August in 2001, 2002, and 2003. Nests were located primarily by observing adult behavior (e.g., carrying nesting material or food) and secondarily by systematically searching nest substrates. Nest fate was monitored every 3-5 d following Martin et al. (1997). A nest was considered successful if one young fledged from the nest. Nests were considered failed when either the nest or eggs were destroyed or when nest activity ceased prior to expected fledging date (after incubation was confirmed). Abandoned nests, in which nest activity ceased prior to confirmed incubation, were removed from analyses.

Vegetation characteristics describing the nest patch (0.04-ha circular plot centered on the nest) were measured for the most common species (Northern Cardinal) following a modified Breeding Bird Survey Protocol (BBIRD) (Martin et al. 1997) from late July through August in 2001 and 2002. Nest-patch characteristics measured included distance of the nest from the nearest forest edge, number and diameter $(1.4 \mathrm{~m}$ above the ground) of tree species, number of snags, amount of course woody debris $(\operatorname{logs}[\geq 7.5 \mathrm{~cm}$ diameter and $\geq 1$ 
$\mathrm{m}$ long] and stumps), understory vegetation volume $(\leq 3 \mathrm{~m})$, and percent canopy cover (measured with an ocular tube) (James and Shugart 1970, Martin et al. 1997). We measured characteristics of nest placement within each nest substrate, including nest height, nest substrate species, number of branches supporting the nest, diameter of support branches, distance of the nest from the central axis of the nest substrate, and distance of the nest from the nearest foliage edge.

\section{Artificial nest experiment}

Artificial nest studies can provide an index to depredation pressures, but they cannot accurately measure real depredation as experienced by nesting birds because they lack parental influences, such as nest concealment and defense (e.g., Yahner and Scott 1988, Donovan et al. 1997, Keyser et al. 1998). Use of large (e.g., quail) eggs may further bias artificial nest studies because they discriminate against small predators (Haskell 1995), but biases can be minimized with use of plasticine eggs, which allow effective sampling of both small and large predators (Donovan et al. 1997, Keyser et al. 1998). Despite these shortcomings, artificial nest studies are valuable because they can measure relative differences in depredation risk among treatments.

Artificial nests were placed within a rural $(<10 \%$ urban land cover within $1 \mathrm{~km}$ ) landscape at one site in 2001 ( $n=29$ nests $)$ and two sites in $2002(n=50$ nests). We used old Northern Cardinal and American Robin nests and baited each nest with one clay egg (Van Aken International, Rancho Cucamonga, California, USA) shaped to resemble a Northern Cardinal egg $(\sim 25 \times 18 \mathrm{~mm})$. Eggs were fashioned while wearing latex gloves and exposed for at least $2 \mathrm{~d}$ prior to the start of the experiment (Major and Kendal 1996). Nests were placed every $25 \mathrm{~m}$ along one transect, 50 $\mathrm{m}$ from and paralleling the river (Wilcove 1985, Haskell 1995), and 50-75 $\mathrm{m}$ from the forest edge. We placed nests in the nearest substrate along the transect alternating between honeysuckle $(n=24)$, rose $(n=$ $28)$, and native $(n=27)$ nest substrates when possible. To control for the effect of nest height, each nest was placed at similar heights (mean nest height ranged from 0.89 to $1.58 \mathrm{~m}$ ). After the initial placement, nests were checked every $3 \mathrm{~d}$ over a 12 -d period; the average number of incubation days for Northern Cardinals. Latex gloves and rubber boots were worn during nest placement and at subsequent nest checks (Rudnicky and Hunter 1993, Whelan et al. 1994). Artificial nest characteristics were measured for all nests placed in 2001 and 2002 including amount of visual concealment (measured at eye level $1 \mathrm{~m}$ from the nest in four cardinal directions [Martin et al. 1997]), nest height, distance of the nest from the nearest foliage edge of the nest substrate, and distance of the nest from the central axis. A nest was considered depredated if the egg was missing, scratched, punctured, or bitten.

\section{Data analysis}

Prior to running analyses, variables not meeting the assumption of normality were transformed $(\log [x+1]$, $\sqrt{x+0.5}$, or $\sqrt{x+1})$. In two cases, we discovered highly correlated variables and removed one member of the pair from analyses. Percentage of urban and agricultural land cover were negatively correlated $(r=$ $-0.63, P=0.03$ ), thus we retained urban cover given our interest in the consequences of urbanization. In addition, distance of the nest to the river was negatively correlated with distance to forest edge $(r=-0.64, P$ $<0.001)$. We dropped distance to river because we believed that the anthropogenic edge was more relevant to nest predation in our study system.

Land cover data were placed into two distinct categories based on the percentage of urban land cover within $1 \mathrm{~km}$ of each site. Urbanizing landscapes $(n=$ 6) were classified as those containing $>10 \%$ urban land cover within $1 \mathrm{~km}$. Landscapes containing $<10 \%$ urban land cover were classified as rural $(n=6$; Table 1$)$. These landscapes also differed qualitatively, such that rural landscapes contained only dispersed single-family homes, while urbanizing landscapes contained strip malls and concentrated residential developments.

Daily mortality rates (DMR) were calculated per site and per nest substrate (honeysuckle, rose, and native species) for natural nests following Mayfield's (1961) method. To avoid confounding nest height with nest substrate, only Northern Cardinal and American Robin nests $\leq 5 \mathrm{~m}$ tall were used in analyses. Within this understory layer, both native and exotic plants were relatively common, whereas native species dominated the midstory and canopy layers. Nests of Northern Cardinals and American Robins were lumped due to small sample sizes; however, because these species are similar in size and nest in similar locations and landscapes, we believe that combining species does not confound the data.

Chi-square approximations were used to test for between year differences in nest fate for both natural and artificial nests (Proc Freq; SAS Institute 1990). Nest data were pooled across years, as fate did not differ between years $\left(\chi^{2}=4.18, \mathrm{df}=2, P=1.24\right)$. Moreover, substrate use did not vary over the breeding season (Borgmann 2002). Artificial nest data were also pooled across years and sites, because the percentage of depredated nests did not differ between years $\left(\chi^{2}=1.12\right.$, $\mathrm{df}=1, P=0.289)$ or between sites $\left(\chi^{2}=2.09\right.$, df $=$ $1, P=0.148)$.

We then used GENMOD to determine if daily mortality rates for natural nests differed based on (1) nest substrate, (2) land use, or (3) the interaction between nest substrate and land use (Proc Genmod; SAS Institute 1990). Because sample sizes ( $n=79$ at two sites) in the artificial nest study prevented us from using DMR, we used chi-square approximations to test for differences in the percentage of depredated artificial 
TABLE 1. Site width, land cover and land use types within $1 \mathrm{~km}$ of nest searching sites, and daily mortality rates for nests monitored in central Ohio, 2001-2003.

\begin{tabular}{|c|c|c|c|c|c|c|c|c|}
\hline \multirow[b]{2}{*}{ Site } & \multirow{2}{*}{$\begin{array}{l}\text { Mean site } \\
\text { width }(\mathrm{m})\end{array}$} & \multicolumn{3}{|c|}{ Land cover $(\%)$} & \multirow{2}{*}{$\begin{array}{l}\text { Land use } \\
\text { category } \dagger\end{array}$} & \multirow{2}{*}{$\begin{array}{c}\text { No. } \\
\text { nests } \$\end{array}$} & \multirow{2}{*}{$\begin{array}{l}\text { Exposure } \\
\text { days }\end{array}$} & \multirow{2}{*}{$\begin{array}{c}\text { Daily } \\
\text { mortality } \\
\text { rate } \$\end{array}$} \\
\hline & & Urban & Agriculture & Forest & & & & \\
\hline Casto Park & 142 & 47.2 & 26.7 & 24.6 & urban & 37 & 434.5 & 0.055 \\
\hline Cherrybottom Park\| & 150 & 31.2 & 35.4 & 28.9 & urban & 6 & 48.5 & 0.103 \\
\hline Darby Public Hunting & 140 & 1.0 & 58.3 & 39.7 & rural & 17 & 233 & 0.047 \\
\hline Elkrun Park & 160 & 12.6 & 66.6 & 17.8 & urban & 21 & 219 & 0.046 \\
\hline Galena & 200 & 1.2 & 42.1 & 42.5 & rural & 16 & 193.5 & 0.067 \\
\hline Kilbourne\| & 116 & 0.4 & 62.5 & 35.5 & rural & 5 & 50 & 0.080 \\
\hline Lou $\|$ & 156 & 53.0 & 25.4 & 8.9 & urban & 9 & 90 & 0.078 \\
\hline North GalenaII & 110 & 0.1 & 46.0 & 53.2 & rural & 6 & 47.5 & 0.105 \\
\hline Rush run & 150 & 21.0 & 9.6 & 61.0 & urban & 16 & 167 & 0.072 \\
\hline South Galena & 158 & 0.1 & 50.2 & 12.0 & rural & 25 & 322.5 & 0.047 \\
\hline Three Creeks & 113 & 7.8 & 73.3 & 15.4 & rural & 11 & 178 & 0.039 \\
\hline Woodside Green Park & 106 & 17.8 & 47.7 & 29.2 & urban & 19 & 222.5 & 0.067 \\
\hline
\end{tabular}

$\dagger$ Based on the percentage of urban land cover within $1 \mathrm{~km}$ of nest sites (urban $>10 \%$; rural $<10 \%$ ).

\$ Northern Cardinal and American Robin nests $\leq 5 \mathrm{~m}$ above ground.

$\S$ Mayfield estimates.

\| Nests monitored only in one year of the study.

II Nests monitored only during two years of the study.

nests among nest substrates for each exposure day (Proc Freq; SAS Institute 1990). We compared the differences in nest placement and nest patch characteristics among nests in honeysuckle, rose, and native nest substrates for both the natural nest study and the artificial nest study with multiple analysis of variance (MANOVA; SAS Institute 1990), which controlled experimentwise error at alpha $=0.05$. If Wilks' lambda was significant $(P<0.05)$, a posteriori univariate $F$ tests were used to identify which nest characteristic significantly differed among the nest substrates. Nest placement and nest patch characteristics that differed between substrates were then compared to nest fate (success vs. failure) with MANOVA.

\section{RESULTS}

\section{Natural nest study}

A total of 143 Northern Cardinal and 45 American Robin nests ( $\leq 5 \mathrm{~m}$ tall) were monitored during 2001,

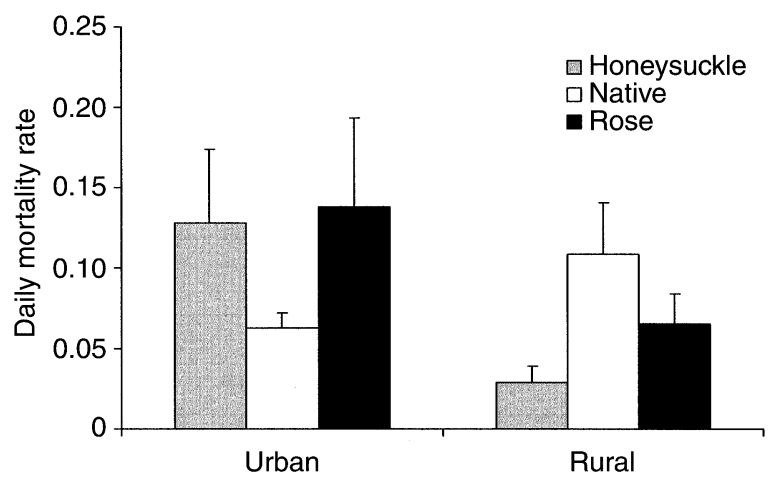

FIG. 1. Daily mortality rates for Northern Cardinal and American Robin nests ( $\leq 5 \mathrm{~m})$ in honeysuckle, rose, and native nest substrates within rural and urban landscapes $(n=$ 188 nests). Land uses were categorized as follows: rural, $<10 \%$ urbanization $(n=6)$; urban, $>10 \%$ urbanization $(n=$ 6) within $1 \mathrm{~km}$ of each site.
2002, and 2003 ( $n=188$ nests with 2206 exposure days; Table 1). Of these nests, $24 \%$ were in honeysuckle, $28 \%$ in rose, and $48 \%$ in native substrates. Nests in native substrates were primarily $(76 \%)$ located in small trees or saplings (e.g., boxelder). Daily mortality rates (DMR) did not significantly differ based on land use $\left(\chi^{2}=2.09\right.$, df $\left.=1, P=0.148\right)$ or nest substrate $\left(\chi^{2}=0.86\right.$, df $\left.=1, P=0.650\right)$ alone. Instead, the effect of exotic shrubs on DMR varied with land use $\left(\chi^{2}=5.90, \mathrm{df}=2, P=0.052\right)$, such that nests in exotic shrubs in urbanizing landscapes were particularly vulnerable to predation (Fig. 1).

Based on 68 Northern Cardinal nests ( $\leq 5 \mathrm{~m}$ tall), both nest placement (Wilks' lambda $F_{10,108}=7.97, P$ $<0.001$ ) and nest patch (Wilks' lambda $F_{20,112}=5.12$, $P<0.001)$ characteristics differed among nests in honeysuckle, rose, and native nest substrates. All nest placement characteristics, except distance of the nest to the nearest foliage edge, differed among nests in honeysuckle, rose, and native nest substrates (Table 2, Fig. 2). Northern Cardinal nests in native nest substrates were nearly two and a half times higher than nests in either rose or honeysuckle $\left(F_{2,58}=28.16, P<\right.$ 0.001). Distance of the nest from the central axis of the nest substrate also differed, with nests in rose shrubs placed closer to the central axis of the shrub $\left(F_{2,58}=5.25, P=0.008\right)$. Nests in native substrates were supported by more $\left(F_{2,58}=3.81, P=0.028\right)$ and larger diameter branches $\left(F_{2,58}=8.94, P<0.001\right)$ than nests in either rose or honeysuckle. Of the nest patch characteristics, only exotic shrub volume $\left(F_{2,65}=\right.$ $44.49, P<0.001)$, native woody vegetation volume $\left(F_{2,65}=6.34, P=0.003\right)$, and distance of the nest to the forest edge $\left(F_{2,65}=4.34, P=0.017\right)$ differed among nest substrates (Table 2, Fig. 3). Differences were such that nests in exotic shrubs had six to nine times more exotic shrub volume surrounding the nest (i.e., in the 
TABle 2. Mean (and $1 \mathrm{SE}$ ) and associated $P$ values of nest-placement and nest-patch characteristics for Northern Cardinal nests ( $\leq 5 \mathrm{~m}$ above ground) within honeysuckle, rose, and native nest substrates in riparian forests in central Ohio, 20012002 .

\begin{tabular}{|c|c|c|c|c|}
\hline \multirow[b]{2}{*}{ Variable } & \multicolumn{3}{|c|}{ Nest substrate } & \multirow[b]{2}{*}{$P$} \\
\hline & Honeysuckle & Rose & Native & \\
\hline \multicolumn{5}{|l|}{ Nest-placement characteristic } \\
\hline Nest height $(\mathrm{m})$ & $1.9(0.23)$ & $1.1(0.08)$ & $2.9(0.25)$ & $<0.001$ \\
\hline Number of support branches & $3.4(0.19)$ & $2.9(0.18)$ & $3.5(0.21)$ & 0.028 \\
\hline Diameter of support branches $(\mathrm{cm})$ & $0.9(0.08)$ & $0.8(0.05)$ & $1.5(0.20)$ & $<0.001$ \\
\hline Distance of nest to nearest foliage edge (m) & $0.6(0.09)$ & $0.4(0.05)$ & $0.5(0.09)$ & 0.104 \\
\hline Distance of nest from central axis $(\mathrm{m})$ & $1.1(0.20)$ & $0.6(0.08)$ & $1.2(0.25)$ & 0.008 \\
\hline \multicolumn{5}{|l|}{ Nest-patch characteristic } \\
\hline Number of small trees $(>8$ and $<23 \mathrm{~cm} \mathrm{dbh})$ & $15.3(1.65)$ & $16.4(1.55)$ & $11.8(1.32)$ & 0.081 \\
\hline Number of medium trees ( $\geq 23$ and $<38 \mathrm{~cm} \mathrm{dbh}$ ) & $4.7(0.90)$ & $4.5(0.46)$ & $3.8(0.55)$ & 0.606 \\
\hline Number of large trees $(\geq 38 \mathrm{~cm} \mathrm{dbh})$ & $2.7(0.44)$ & $2.6(0.39)$ & $3.0(0.32)$ & 0.455 \\
\hline Number of snags & $1.4(0.37)$ & $2.4(0.51)$ & $2.1(0.39)$ & 0.254 \\
\hline Amount of coarse woody debris & $9.9(1.59)$ & $2.4(0.51)$ & $11.4(1.69)$ & 0.745 \\
\hline Canopy cover $(\%)$ & $85.0(3.09)$ & $76.4(3.59)$ & $75.8(3.99)$ & 0.222 \\
\hline Forb volume $(\leq 3 \mathrm{~m})$ & $0.5(0.17)$ & $1.0(0.17)$ & $1.0(0.25)$ & 0.174 \\
\hline Exotic shrub volume $(\leq 3 \mathrm{~m})$ & $2.5(0.28)$ & $1.6(0.16)$ & $0.3(0.12)$ & $<0.001$ \\
\hline Native woody vegetation volume $(\leq 3 \mathrm{~m})$ & $0.7(0.08)$ & $1.6(0.20)$ & $1.4(0.20)$ & 0.003 \\
\hline Distance to edge & $27.7(7.40)$ & $53.9(7.88)$ & $60.0(7.68)$ & 0.017 \\
\hline
\end{tabular}

Note: Nest-placement (Wilks' lambda $F_{10,108}=7.97, P<0.001$ ) and nest-patch characteristics (Wilks' lambda $F_{20,112}=$ 5.12, $P<0.001)$ differed significantly among nest substrates.

nest patch) than nests in native nest substrates. Nests in honeysuckle were also closer to the forest edge than nests in other substrates. Although these nest placement and nest patch characteristics varied between nests substrates (Tables 2 and 3), none significantly affected nest fate $\left(F_{7,53}=1.52, P=0.181\right)$.

\section{Artificial nest experiment}

The percentage of artificial nests depredated differed among nests in honeysuckle, rose, and native nest substrates after the third exposure day $\left(\chi^{2}=6.54\right.$, df $=$ 2, $P=0.038$ ), but did not differ thereafter (day $6, \chi^{2}$ $=2.33$, df $=2, P=0.312$; day $9, \chi^{2}=1.67, \mathrm{df}=2$, $P=0.435$; day $12, \chi^{2}=0.886$, df $\left.=2, P=0.642\right)$, as the majority of nests already were depredated (Fig. 4). More nests in honeysuckle were depredated than nests in rose or native nest substrates after the third exposure day (Fig. 4). Differences among honeysuckle, rose, and native nest substrate growth form lead to differences in horizontal concealment and distance of the nest from the central axis $\left(F_{2,67}=17.99, P<0.001\right.$; $F_{2,67}=4.61, P=0.01$, respectively); however, neither variable affected nest fate $\left(F_{2,67}=0.49, P=0.617\right.$; Table 3).

\section{DISCUSSION}

Both natural and artificial nests demonstrated that exotic shrubs negatively affected predation rates of understory $(\leq 5 \mathrm{~m})$ nesting birds, however the negative effect of exotic shrubs varied with the landscape matrix. Nests in exotic shrubs in urbanizing landscapes experienced higher daily mortality rates (DMR) than those in more rural landscapes. Although exotic shrubs in the natural nest study did not appear to negatively impact nest success in rural landscapes, results from
FIG. 2. Nest-placement characteristics within each nest substrate for understory $(\leq 5 \mathrm{~m}$ above ground) Northern Cardinal nests ( $n=$ 68). Nest placement characteristics differed among nest substrates $\left(F_{10,108}=7.97, P=\right.$ $<0.001)$.

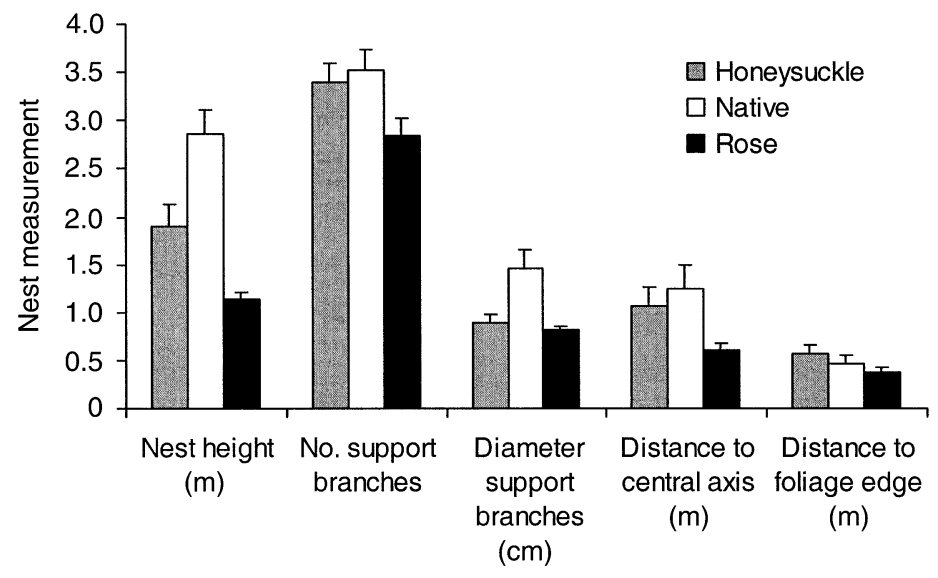




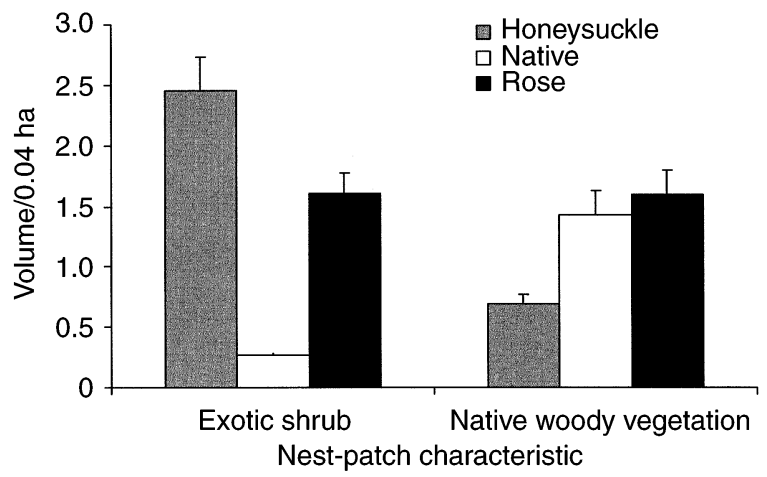

FIG. 3. Nest-patch characteristics for understory $(\leq 5 \mathrm{~m}$ above ground) Northern Cardinal nests $(n=68)$ within 0.04 ha of the center of the nest. Exotic shrub volume $\left(F_{2.65}=\right.$ $44.49, P=<0.001)$ and native woody vegetation volume $\left(F_{2,65}=6.03, P=0.004\right)$ differed significantly among nest substrates. "Exotic shrub" is an index of the volume of exotic shrubs $\leq 3 \mathrm{~m}$ in height and "native woody vegetation" is an index of the volume of all native vegetation (trees, shrubs, and vines) $\leq 3 \mathrm{~m}$ in height.

the artificial nest experiment indicate that exotic shrubs in rural landscapes can still reduce nest success.

Several other studies also have suggested that exotic plants negatively affect avian communities by altering species abundance (Anderson et al. 1977, Braithwaite et al. 1989, Mills et al. 1989, Rottenborn 1997, 1999, Germaine et al. 1998, Benoit and Askins 1999), species guilds (Hunter et al. 1988, Fraser and Crowe 1990, Ellis 1995), brood parasitism rates (Anderson et al. 1977, Reichard et al. 2001), and nest success (Schmidt and Whelan 1999, Remes 2003). Few of these studies, however, measured other local and landscape variables (e.g., distance from edge and surrounding land uses), potentially confounding their results. Because exotic shrubs are more abundant near forest edges in many systems (Brothers and Spingarn 1992, Luken et al. 1995, Luken and Goessling 1995, Goldblum and Beatty 1999), reduced nest success could result from increased edge-related nest predation (Gates and Gysel 1978, Paton 1994, King et al. 1996), rather than from the exotic nest substrate. Although honeysuckle volume was negatively related to distance from the forest edge (Borgmann 2002) and nests in honeysuckle were closer to the forest edge, there was no edge-related pattern in nesting success within each of the nest substrates. Therefore, our results provide compelling evidence that the nest substrate itself, rather than its location within a site, is responsible for increased predation.

Although specific mechanisms of increased vulnerability of nests in exotic shrubs are unclear, there have been several proposed hypotheses. Differences in nest placement and shrub growth form between native and exotic nest substrates have been suggested to increase predation risk (Braithwaite et al. 1989, Schmidt and Whelan 1999). Nest height can be an important factor affecting nest success (Best and Stauffer 1980, Filliater et al. 1994) as ground-foraging mammals, such as raccoons (Procyon lotor), and small mammals are more likely to encounter nests lower to the ground (Schmidt 1999). This may, in part, explain the pronounced differences in DMR among nest substrates in urbanizing landscapes, where higher numbers of nest predators (A. D. Rodewald, unpublished data) and domestic cats (Felis domesticus; K. L. Borgmann, personal observation) were regularly observed. Based on marks present on recovered clay eggs, $68 \%$ of the predation events were attributed to mammals, while avian predators accounted for only $19 \%$ of the depredated eggs.

Structural differences between native and exotic shrubs also may affect predation rates. Schmidt and Whelan (1999) suggest that the presence of thorns on native shrubs may have prevented predator (e.g., raccoon) access, reducing predation rates, however multiflora rose, which contains multiple thorns, experienced high rates of nest predation in our study. Interestingly, mammals depredated artificial nests with thorns more frequently than artificial nests without thorns. This discrepancy may be due to different predator assemblages at each study site or to other factors not yet understood. Lateral concealment of the nest also may contribute to increased predation (Martin and Roper 1988), although nests in honeysuckle and rose were generally better concealed (honeysuckle $=47.34 \pm$ $8.75 ;$ native $=10.94 \pm 5.98 ;$ rose $=62.14 \pm 4.96$ [mean $\pm 1 \mathrm{SE}]$ ). Other structural differences such as number and size of support branches may limit predator access to nests, however it is unclear how plant structures affect predator foraging behavior.

Vegetation characteristics within the nest patch are thought to affect nest success in a number of ways (Martin and Roper 1988, Martin 1992, 1993b). First, exotic shrubs often reduce the diversity of nest substrates, resulting in less nest-site partitioning. This uniformity can increase predation because predators can

TABLE 3. Mean (and $1 \mathrm{SE}$ ) artificial nest characteristics and associated $P$ values of artificial nests in honeysuckle, rose, and native nest substrates in riparian forests in central Ohio, 2001-2002.

\begin{tabular}{|c|c|c|c|c|}
\hline \multirow[b]{2}{*}{ Artificial nest characteristic } & \multicolumn{3}{|c|}{ Nest substrate } & \multirow[b]{2}{*}{$P$} \\
\hline & Honeysuckle & Rose & Native & \\
\hline Lateral concealment $(\%)$ & $20.7 \quad(4.26)$ & $64.3(5.24)$ & $16.3(4.39)$ & $<0.001$ \\
\hline Distance of nest to nearest foliage edge $(\mathrm{m})$ & $0.5 \quad(0.05)$ & $0.4(0.04)$ & $0.4(0.04)$ & 0.280 \\
\hline Distance of nest from central axis $(\mathrm{m})$ & $0.04(0.10)$ & $0.2(0.05)$ & $0.2(0.06)$ & 0.013 \\
\hline
\end{tabular}




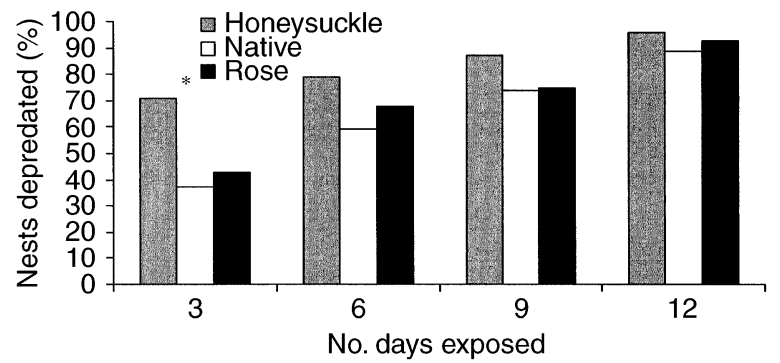

FIG. 4. Percentage of depredated artificial nests in relation to the number of days exposed. The percentage of artificial nests depredated differed among nests in honeysuckle, rose, and native nest substrates after the third exposure day $\left(\chi^{2}=\right.$ $6.54, \mathrm{df}=2, P=0.038)$, but did not differ thereafter. The artificial nest experiment began on 18 June 2001 at one rural site and on 30 June 2002 at two rural sites in Delaware County, Ohio, USA.

focus their efforts on specific nest sites or patches (Martin 1987, 1988b, 1993b). For example, Martin (1988b, $1993 b$ ) found that predation rates dropped when nests were segregated among different substrates and placed at varying heights. Because exotic shrubs dominated the understory at our sites and because nests in exotic shrubs were placed at similar heights, these similarities may have facilitated predator search image allowing predators to focus their efforts on specific nest types (Bowman and Harris 1980, Martin 1987, 1988b, c, 1993b, Schmidt and Whelan 1998, Chase 2002). Second, dense patches of vegetation may have a higher probability of containing nests, which can increase density dependent predation (Martin and Roper 1988, Martin 1988b, $c$, Schmidt and Whelan 1998, Schmidt 1999).

Although few of these characteristics affected nest fate in our study system, birds may not have had enough time to respond to recent changes in habitat structure that result from invasion by exotic plants (Gates and Gysel 1978, Siepielski et al. 2001, Chase 2002). Moreover, gene flow from nearby forest patches also can prevent or reduce adaptation (Misenhelter and Rotenberry 2000). In addition, the lack of association between nest-site characteristics and nest fate may result if the predator community is diverse, as different search behaviors can preclude "safe" nest sites (Filliater et al. 1994, Misenhelter and Rotenberry 2000, Chase 2002).

An important finding that distinguishes our study from others is that the landscape matrix appeared to mediate the influence of exotic shrubs, such that nests in exotic shrubs were particularly vulnerable in urbanizing landscapes. This may, in part, be explained by several important differences between riparian forests in rural and urbanizing landscapes. First, exotic shrubs, especially honeysuckle, are more likely to dominate the understory shrub community in urbanizing landscapes (Borgmann 2002). Thus, in urbanizing landscapes exotic shrubs can decrease nest-site partitioning, which may increase predation risk. Predators also may show a functional response, increasing search effort in areas with dense patches of exotic shrubs, as dense patches of vegetation are likely to contain more nests (Martin 1988c). Second, urban landscapes typically maintain higher numbers of nest predators (Matthiae and Stearns 1981, Oehler and Litvaitis 1996, Haskell et al. 2001). In our study area, urban landscapes contained nearly three times the number of nest predators than rural landscapes (A. D. Rodewald, unpublished data), including American Crows (Corvus brachyrhynchos), Blue Jays, (Cyanocitta cristata), domestic cats, eastern gray squirrels (Sciurus carolinensis), eastern chipmunks (Tamias striatus), and raccoons. Third, prey (i.e., bird) density could differ between landscapes such that density-dependent factors would contribute to differences in DMR among nest substrates. However, surveys of breeding birds at our sites indicate that the number of understory-nesting birds did not differ between rural and urbanizing landscapes (A. D. Rodewald, unpublished data). Therefore, density-dependent predation is likely not responsible for increased daily mortality although density dependence was not directly tested. In sum, birds nesting in exotic shrubs were more vulnerable to predation, particularly in urbanizing landscapes where exotic shrubs and nest predators were more abundant. We suggest this increased vulnerability stems from differences in nest-placement and nestpatch characteristics that may facilitate the ability of mammals to locate nests in exotic shrubs.

\section{CONSERVATION IMPLICATIONS}

It is critical that ecologists and land managers understand the interactions among exotic plants and wildlife species, especially as exotic plants become more prevalent (Reichard et al. 2001, Zavaleta et al. 2001, Byers et al. 2002). This study was the first to demonstrate that exotic shrubs can negatively impact avian nest success while explicitly accounting for both distance from edge and the landscape matrix. These findings have several important implications for land managers and biologists. First, because invasion of exotic shrubs is tied to the landscape matrix (Borgmann 2002), and landscape matrix characteristics (i.e., urbanization) exacerbated the negative impacts of exotic shrubs, managers can identify forest reserves where avian communities may be especially vulnerable and require additional conservation attention. Second, city planners and managers can take a proactive approach by addressing land uses that increase invasion risk. For example, low-development buffer zones surrounding forest reserves may reduce invasion by exotic plants (Hobbs and Humphries 1995, Pysek et al. 2002). Third, at the local scale, restoring the native shrub community, especially in urban landscapes, may prove to be a viable strategy to improve nest success for species already at risk (Donovan and Flather 2002). 
Exotic plants likely impact songbirds in more ways than just nest success (Braithwaite et al. 1989, Fraser and Crowe 1990, Reichard et al. 2001, Renne et al. 2002) however, not all of these effects are negative. For example, fruit-producing exotic shrubs may be important food resources for migrating and overwintering passerines, especially in areas lacking native fruits (Reichard et al. 2001). Because our understanding of how exotic plants affect songbirds is limited, additional research is needed to (1) determine if exotic shrubs impact annual productivity, (2) better identify the underlying causes of decreased nesting success in exotic shrubs, and (3) determine if selection of exotic shrubs is an adaptive or nonadaptive behavior.

\section{ACKNOWLEDGMENTS}

Generous financial support was provided by The Ohio State University's School of Natural Resources, The Ohio Agricultural and Research Development Center, and the C. William Swank Program of Rural-Urban Policy. We are grateful to M. Bakermans, A. Vitz, A. Kornowa, E. Eiben, B. Graves, P. Rodewald, M. Santiago, S. Hazzard, M. Nelson, L. Leston, J. Blanco, K. Atchison, and J. Gray for field assistance. M. Bakermans, N. Stricker, and D. Risely assisted with landscape analysis. We also thank Ohio Recreation and Parks Department, Franklin County MetroParks, and private landowners for allowing access to field sites. Thanks to A. Snow and R. Gates for providing helpful comments throughout this research and to C. Whelan, K. Schmidt, and J. Brawn for providing valuable comments on earlier drafts of this manuscript.

\section{Literature Cited}

Anderson, B. W., A. Higgins, and R. D. Ohmart. 1977. Avian use of saltcedar communities in the lower Colorado River valley. U.S. Department of Agriculture Forest Service General Technical Report RM-43.

Benoit, L. K., and R. A. Askins. 1999. Impacts of the spread of Phragmites on the distribution of birds in Connecticut tidal marshes. Wetlands 19:194-208.

Best, L. B., and D. F. Stauffer. 1980. Factors affecting nesting success in riparian bird communities. Condor 82:149-158.

Borgmann, K. L. 2002. Invasion of riparian forests by exotic shrubs: effects of landscape matrix and implications for breeding birds. Thesis. The Ohio State University, Columbus, Ohio, USA.

Bowman, G. B., and L. D. Harris. 1980. Effect of spatial heterogeneity on ground-nest depredation. Journal of Wildlife Management 44:806-813.

Braithwaite, R. W., W. M. Lonsdale, and J. A. Estbergs. 1989. Alien vegetation and native biota in tropical Australia: the impact of Mimosa pigra. Biological Conservation 48:189210.

Brothers, T. S., and A. Spingarn. 1992. Forest fragmentation and alien plant invasion of central Indiana old-growth forests. Conservation Biology 6:91-100.

Byers, J. E., S. Reichard, J. M. Randall, I. M. Parker, C. S. Smith, W. M. Lonsdale, I. A. E. Atkinson, T. R. Seastedt, M. Williamson, E. Chornesky, and D. Hayes. 2002. Directing research to reduce the impacts of nonindigenous species. Conservation Biology 16:630-640.

Chase, M. K. 2002. Nest site selection and nest success in a song sparrow population: the significance of spatial variation. Condor 104:103-116.

D'Antonio, C., L. A. Meyerson, and J. Denslow. 2001. Exotic species and conservation. Pages 59-80 in M. E. Soule and G. H. Orians, editors. Conservation biology: research priorities for the next decade. Island Press, Washington, D.C., USA.
Donovan, T. M., and C. H. Flather. 2002. Relationships among North American songbird trends, habitat fragmentation, and landscape occupancy. Ecological Applications 12:364-374

Donovan, T. M., P. W. Jones, E. M. Annand, and F. R. Thompson III. 1997. Variation in local-scale edge effects: mechanisms and landscape context. Ecology 78:2064-2075.

Ellis, L. M. 1995. Bird use of saltcedar and cottonwood vegetation in the Middle Rio Grande Valley of New Mexico, USA. Journal of Arid Environments 30:339-349.

Filliater, T. S., R. Breitwisch, and P. M. Nealen. 1994. Predation on Northern Cardinal nests: does choice of nest site matter? Condor 96:761-768.

Flather, C. H., and J. R. Sauer. 1996. Using landscape ecology to test hypotheses about large-scale abundance patterns in migratory birds. Ecology 77:28-35.

Fraser, M. W., and T. M. Crowe. 1990. Effects of alien woody plant invasion on the birds of Mountain Fynbos in the Cape of Good Hope Nature Reserve. South African Journal of Zoology 25:97-108.

Gates, J. E., and L. W. Gysel. 1978. Avian nest dispersion and fledging success in field-forest ecotones. Ecology 59: 871-883.

Germaine, S. S., S. S. Rosenstock, R. E. Schweinsburg, and W. S. Richardson. 1998. Relationships among breeding birds, habitat, and residential development in greater Tucson, Arizona. Ecological Applications 8:680-691.

Goldblum, D., and S. W. Beatty. 1999. Influence of an old field/forest edge on a northeastern United States deciduous forest understory community. Journal of the Torrey Botanical Society 126:335-343.

Groom, J. D., and T. C. Grubb, Jr. 2002. Bird species associated with riparian woodland in fragmented, temperatedeciduous forest. Conservation Biology 16:832-836.

Haskell, D. G. 1995. A reevaluation of the effects of forest fragmentation on rates of bird-nest predation. Conservation Biology 9:1316-1318.

Haskell, D. G., A. M. Knupp, and M. C. Schneider. 2001. Nest predator abundance and urbanization. Pages 243-258 in J. M. Marzluff, R. Bowman, and R. Donnelly, editors. Avian ecology and conservation in an urbanizing world. Kluwer Academic Publishers, Boston, Massachusetts, USA.

Hobbs, R. J. 2000. Land-use changes and invasions. Pages 55-64 in H. A. Mooney and R. J. Hobbs, editors. Invasive species in a changing world. Island Press, Washington, D.C., USA.

Hobbs, R. J., and S. E. Humphries. 1995. An integrated approach to the ecology and management of plant invasions. Conservation Biology 9:761-770.

Hunter, W. C., R. D. Ohmart, and B. W. Anderson. 1988. Use of exotic saltcedar (Tamarix chinensis) by birds in arid riparian systems. Condor 90:113-123.

James, F. C., and H. H. Shugart, Jr. 1970. A quantitative method of habitat description. Audubon Field Notes 24: 727-736.

Keyser, A. J., G. E. Hill, and E. C. Soehren. 1998. Effects of forest fragment size, nest density, and proximity to edge on the risk of predation to ground-nesting passerine birds. Conservation Biology 12:986-994.

King, D. I., C. R. Griffin, and R. M. DeGraaf. 1996. Effects of clearcutting on habitat use and reproductive success of the ovenbird in forested landscapes. Conservation Biology 10:1380-1386.

Laub, K. W. 1979. Changing land use: forests, farms, and wildlife. Pages 272-281 in M. B. Lafferty, editor. Ohio's natural heritage. Ohio Academy of Sciences, Columbus, Ohio, USA.

Luken, J. O., and N. Goessling. 1995. Seedling distribution and potential persistence of the exotic shrub Lonicera 
maackii in fragmented forests. American Midland Naturalist 133: $124-130$.

Luken, J. O., T. C. Tholemeier, L. M. Kuddes, and B. A. Kunkel. 1995. Performance, plasticity, and acclimation of the nonindigenous shrub Lonciera maackii (Caprifoliaceae) in contrasting light environments. Canadian Journal of Botany 73:1953-1961.

Major, R. E., and C. E. Kendal. 1996. The contribution of artificial nest experiments to understanding avian reproductive success: a review of methods and conclusions. Ibis 138:298-307.

Martin, T. E. 1987. Artificial nest experiments: effects of nest appearance and predator type. Condor 89:925-928.

Martin, T. E. 1988a. Habitat and area effects on forest bird assemblages: is nest predation an influence? Ecology 69: 74-84.

Martin, T. E. 1988b. Processes organizing open-nesting bird assemblages: competition or nest predation? Evolutionary Ecology 2:37-50.

Martin, T. E. $1988 c$. On the advantage of being different: nest predation and the coexistence of bird species. Proceedings of the National Academy of Sciences (USA) 85 : 2196-2199.

Martin, T. E. 1992. Breeding productivity considerations: what are the appropriate habitat features for management? Pages 455-473 in J. M. Hagan III and D. W. Johnston, editors. Ecology and conservation of neotropical migrant landbirds. Smithsonian Institution Press, Washington, D.C., USA.

Martin, T. E. 1993a. Nest predation among vegetation layers and habitat types: revising the dogmas. American Naturalist 141:897-913.

Martin, T. E. 1993b. Nest predation and nest sites: new perspectives on old patterns. BioScience 43:523-532.

Martin, T. E. 1995. Avian life history evolution in relation to nest sites, nest predation, and food. Ecological Monographs 65:101-127.

Martin, T. E., C. Paine, C. J. Conway, and W. M. Hochachka. 1997. BBIRD field protocol. Montana Cooperative Wildlife Resource Unit, Missoula, Montana, USA.

Martin, T. E., and J. J. Roper. 1988. Nest predation and nestsite selection of a western population of the hermit thrush. Condor 90:51-57.

Matthiae, P. E., and F. Stearns. 1981. Mammals in forest islands in southeastern Wisconsin. Pages 55-66 in R. L. Burgess and D. M. Sharpe, editors. Forest island dynamics in man-dominated landscapes. Springer-Verlag, New York, New York, USA.

Mayfield, H. 1961. Nesting success calculated from exposure. Wilson Bulletin 73:255-261.

Mills, G. S., J. B. Dunning, Jr., and J. M. Bates. 1989. Effects of urbanization on breeding bird community structure in southwestern desert habitats. Condor 91:416-428.

Misenhelter, M. D., and J. T. Rotenberry. 2000. Choices and consequences of habitat occupancy and nest site selection in sage sparrows. Ecology 81:2892-2901.

Moran, M. A. 1984. Influence of adjacent land use on understory vegetation of New York forests. Urban Ecology 8:329-340.

Oehler, J. D., and J. A. Litvaitis. 1996. The role of spatial scale in understanding responses of medium-sized carnivores to forest fragmentation. Canadian Journal of Zoology 74:2070-2079.

Paton, P. W. C. 1994. The effect of edge on avian nest success: how strong is the evidence? Conservation Biology 8:17-26.

Pysek, P., V. Jarosik, and T. Kucera. 2002. Patterns of invasion in temperate nature reserves. Biological Conservation 104:13-24.

Reichard, S. H., L. Chalker-Scott, and S. Buchanan. 2001. Interactions among non-native plants and birds. Pages 179223 in J. M. Marzluff, R. Bowman, and R. Donnelly, editors. Avian ecology and conservation in an urbanizing world. Kluwer Academic Publishers, Boston, Massachusetts, USA.
Remes, V. 2003. Effects of exotic habitat on nesting success, territory density, and settlement patterns in the Blackcap (Sylvia atricapilla). Conservation Biology 17:1127-1133.

Renne, I. J., W. C. Barrow, Jr., L. A. Johnson Randall, and W. C. Bridgers, Jr. 2002. Generalized avian dispersal syndrome contributes to Chinese tallow tree (Sapium sebiferum, Euphorbiaceae) invasiveness. Biodiversity Research 8: 285-295.

Ricklefs, R. E. 1969. An analysis of nesting mortality in birds. Smithsonian Contributions to Zoology 9:1-48.

Robinson, S. K., F. R. Thompson III, T. M. Donovan, D. R. Whitehead, and J. Faaborg. 1995. Regional forest fragmentation and the nesting success of migratory birds. Science 267:1987-1990.

Rodewald, A. D. 2002. Nest predation in forested regions: landscape and edge effects. Journal of Wildlife Management 66:634-640.

Rodewald, A. D., and R. H. Yahner. 2001a. Influence of landscape composition on avian community structure and associated mechanisms. Ecology 82:3493-3504.

Rodewald, A. D., and R. H. Yahner. 2001b. Avian nesting success in forested landscapes: influence of landscape composition, stand and nest-patch microhabitat, and biotic interactions. Auk 118:1018-1028.

Rottenborn, S. C. 1997. The impacts of urbanization on riparian bird communities in central California. Dissertation. Stanford University, Stanford, California, USA.

Rottenborn, S. C. 1999. Predicting the impacts of urbanization on riparian bird communities. Biological Conservation 88:289-299.

Rudnicky, T. C., and M. L. Hunter. 1993. Avian nest predation in clearcuts, forests, and edges in a forest-dominated landscape. Journal of Wildlife Management 57:358-364.

SAS Institute. 1990. SAS-STAT user's guide. SAS Institute, Cary, North Carolina, USA.

Schmidt, K. A. 1999. Foraging theory as a conceptual framework for studying nest predation. Oikos 85:151-160.

Schmidt, K. A., and C. J. Whelan. 1998. Predator-mediated interactions between and within guilds of nesting songbirds: experimental and observational evidence. American Naturalist 152:393-402.

Schmidt, K. A., and C. J. Whelan. 1999. Effects of exotic Lonicera and Rhamnus on songbird nest predation. Conservation Biology 13:1502-1506.

Siepielski, A. M., A. D. Rodewald, and R. H. Yahner. 2001. Nest site selection and nesting success of the Red-eyed Vireo in central Pennsylvania. Wilson Bulletin 113:302-307.

Sieving, K. E., and M. F. Willson. 1998. Nest predation and avian species diversity in Northwestern forest understory. Ecology 79:2391-2402.

Thompson, F. R., III, T. M. Donovan, R. M. DeGraaf, J. Faaborg, and S. K. Robinson. 2002. A multi-scale perspective on the effects of forest fragmentation on birds in eastern forests. Studies in Avian Biology 25:8-19.

U.S. Geological Survey, EROS Data Center. 2000. MRLC regional land cover characterization project land cover data for Ohio early 1900s (version 2000-03). Multi-resolution land characteristics consortium. National Land Cover Data Program. U.S. Geological Survey, EROS Data Center, Sioux Falls, South Dakota, USA.

Whelan, C. J., M. L. Dilger, D. Robson, N. Hallyn, and S. Dilger. 1994. Effects of olfactory cues on artificial-nest experiments. Auk 111:945-952.

Wilcove, D. S. 1985. Nest predation in forest tracts and the decline of migratory songbirds. Ecology 66:1211-1214.

Yahner, R. H., and D. P. Scott. 1988. Effects of forest fragmentation on depredation of artificial nests. Journal of Wildlife Management 52:158-161.

Zavaleta, E. S., R. J. Hobbs, and H. A. Mooney. 2001. Viewing invasive species removal in a whole-ecosystem context. Trends in Ecology and Evolution 16:454-459. 